\title{
Axillary surgical approach in metastatic breast cancer patients: a systematic review and meta-analysis
}

\author{
Fabiana C A P Lisboa ${ }^{1 a}$ (D) , Roberta B Silva ${ }^{2}$, Keitty R C de Andrade ${ }^{3}$, Lucimara P C Veras ${ }^{4}$, Ana Claudia M G Figueiredo and $^{2}$ \\ Maurício G Pereira ${ }^{6}$
}

${ }^{1}$ Faculty of Medicine, University of Brasilia, Brasilia, Distrito Federal 70910-900, Brazil

${ }^{2}$ Nutritionist, Faculty of Health Sciences, University of Brasilia, Brasilia, Distrito Federal 70910-900, Brazil

${ }^{3}$ Physiotherapist, Faculty of Medicine, University of Brasilia, Brasilia, Distrito Federal 70910-900, Brazil

${ }^{4}$ Foundation of Education and Research in Health Sciences, Brasilia, Distrito Federal 70710-907, Brazil

${ }^{5}$ Faculty of Health Sciences, University of Brasilia, Brasilia, Distrito Federal, Brazil

${ }^{6}$ Faculty of Medicine, Brasilia, Distrito Federal 70910-900, Brazil

ahttps://orcid.org/0000-0002-3441-993X

\section{Abstract}

A systematic review and meta-analysis were conducted to evaluate the benefit of an axillary surgical approach on overall survival and secondarily of breast surgery amongst patients with metastatic breast cancer which is considered to be an incurable disease. However, an axillary surgical approach showed no association with overall survival in patients with metastatic breast cancer. The true impact of locoregional therapies on longterm outcomes remains unknown, and randomised clinical trials are needed.

Keywords: breast neoplasms, neoplasm metastasis, surgery, meta-analysis, systematic review

\section{Introduction}

Metastatic breast cancer affects approximately 3.5\%-10\% of patients at primary diagnosis [1, 2]. Although it is potentially treatable, the median overall survival is only about 2-3 years, and only $25 \%$ of the patients will still be alive after 5 years [3]. A systemic approach to treatment is recommended, and locoregional surgery is only indicated in symptomatic cases [4]. However, a surgical approach is an independent factor to improve survival and promote better local control, improving the quality of life and resulting in a mortality reduction [5]. Its use has also been linked to more than $10 \%$ of metastatic patients who live at least 10 years and reduces the risk of death by $30 \%-37 \%[6,7]$.

A surgical approach in metastatic breast cancer is not the standard protocol, but $35 \%-$ $60 \%$ of patients usually receive surgical treatment of the primary tumour $[1,2,8,9]$, and this proportion is higher for those receiving surgery for palliative purposes only [9]. However, observational studies have shown an increase in overall survival associated with surgical treatment despite being controversial data [8]. Prospective studies are expected to answer the questions as to whether there is a benefit in the surgical approach of the breast and/or armpit.

Correspondence to: Fabiana C A P Lisboa Email: fabianachristinalisboa@gmail.com

ecancer 2020, 14:1117

https://doi.org/10.3332/ecancer.2020.1117

Published: 06/10/2020

Received: 19/05/2020

Publication costs for this article were supported by ecancer (UK Charity number 1176307).

Copyright: (c) the authors; licensee ecancermedicalscience. This is an Open Access article distributed under the terms of the Creative Commons Attribution License (http:// creativecommons.org/licenses/by/3.0), which permits unrestricted use, distribution, and reproduction in any medium, provided the original work is properly cited. 
Uncontrolled disease present in the axilla may function as a constant source of disease spread [10]. The reason why an axillary approach to surgery is beneficial for survival is not clearly known, and its indication is controversial [11]. However, the self-dissemination of primary tumour cells to distant sites and an immune suppressive microenvironment can be reduced by surgical resection of the primary tumour combined with a concomitant axillary surgical approach [12]. It is questioned whether axillary emptying would bring greater comorbidity to a patient with a poor prognosis as in this metastatic scenario or whether it could bring benefits in terms of survival and local control.

The purpose of the study is the systematic review and meta-analysis of the axillary surgery approach in metastatic breast cancer (MBC) and secondarily of the breast surgery approach in this same scenario. According to the authors' knowledge, this is the first systematic review and meta-analysis on the subject.

\section{Methods}

\section{Registration and protocol}

This systematic review was recorded in the International Prospective Register of Systematic Reviews (PROSPERO) under the number CRD42017077752 and was conducted based on the checklist for meta-analyses of observational studies (MOOSE) [13] (Appendix S1MOOSE Checklist for Meta-analyses of Observational Studies) and preferred reporting items for systematic reviews and meta-analyses (PRISMA) (Appendix S2-PRISMA checklist) [14]. The Peer Review of Electronic Search Strategies (PRESS) checklist was applied, which is an instrument used for the independent peer review of the search strategy [15].

\section{Eligibility criteria}

We included studies reporting patients who underwent axillary and breast surgical approaches in the presence of metastatic breast cancer and reported performance status for treatment and overall survival outcomes. Studies evaluating inflammatory breast cancer, enrolling those with the only supraclavicular disease or specific groups such as pregnant women, and letters or commentaries were excluded along with studies that had unavailable full texts and those that did not report hazard ratios (HRs) for overall survival.

\section{Information sources and search strategy}

Literature searches were performed up to June 2018. The following databases were used: Medline (by PubMed), Embase, Clinical Trials, Scopus, Web of Science, SciELO, Lilacs, Google Scholar and ProQuest. The authors were contacted if additional information was required. Reference lists of the included records were hand-searched for additional eligible articles.

The search strategy was developed using MeSH terms for PubMed and EMTREE terms for EMBASE, as well as a combination of keywords for the other databases. The search strategy below was used on PubMed and, afterwards, adapted for each database (Appendix S1-Search strategy for each database):

(('breast neoplasms' [Mesh] OR 'breast cancer' OR 'metastatic breast cancer') AND ('stage IV' OR 'stage IV breast cancer' OR 'stage IV metastatic breast cancer') AND ('lymph node excision' [Mesh] OR 'surgical excision' OR surgery OR 'local treatment')).

No restriction of date or status of publication, language or type of study was applied.

\section{Study selection process}

The study selection first consisted of assessing titles and abstracts after the removal of duplicate records. Eligibility assessment was performed by full-text evaluation, and those articles that did not appear to meet the eligibility criteria were excluded. Data from the selected articles were extracted to a Microsoft Excel ${ }^{\circledR}$ spreadsheet (2016). All steps were performed independently by two authors (FCAPL and RBS), and disagreements were resolved by consensus or with the intervention of a third reviewer (KRCA). 


\section{Quality assessment of studies}

The Joanna Briggs Institute tools were used to evaluate the methodological quality of the studies. The checklist for cohort studies [16] evaluated 11 questions related to the similarity between groups, exposure and outcome measures, strategies to control for confounding factors, absence or presence of the outcome at the beginning of follow-up, follow-up time and statistics. The checklist for randomised controlled trials [17] analyses 13 questions about randomisation, group allocation, blinding, intervention, statistical analysis and appropriateness of the study design. The greater the number of 'yes' answers, the higher the probability of having a good methodological quality.

\section{Quality of the evidence}

To evaluate the quality of the evidence across studies through the GRADE evaluation [18], five items were verified that were reduced by two points per item the quality of the evidence: risk of bias, inconsistency, indirect evidence, inaccuracy and publication bias. In parallel, three items increased the quality of evidence by up to two points: magnitude of the effect, dose-response gradient and possible confounding adjustment. According to the GRADE classification, the evidence was considered to be of high quality when it reached at least four points, moderate quality at three points, low quality at two points and very low quality at one point [19].

\section{Risk of bias}

We assessed the risk of bias using Cochrane's risk of bias tool as described in the Cochrane Handbook for Systematic Reviews of Interventions [20].

\section{Data analysis}

The primary endpoint was overall survival in the axillary surgery approach in MBC. The second endpoint was overall survival in breast surgery in this same scenario.

The estimated proportion and its respective confidence interval $(95 \% \mathrm{Cl})$ were considered for analysis. A Chi-square test $\left(\chi^{2}\right)$ was applied amongst studies, with a $p$-value $<0.05$. A sensitivity analysis was performed. The heterogeneity amongst studies was measured using the I-squared statistic $\left(I^{2}\right)$ [21]. The values of $75 \%$ indicate high heterogeneity, values of $50 \%$ moderate heterogeneity and $<25 \%$ low heterogeneity [22]. Random effect meta-analyses were performed using the Der Simonian-Laird method [23] considering HR measures with 95\% confidence intervals $(95 \% \mathrm{CI})$. STATA ${ }^{\circledR}$ version 15 was used in all statistical analyses.

\section{Results}

\section{Study selection}

A total of 13,377 studies were retrieved from database searches after the removal of duplicate records and title/abstracts screening (Figure 1). One hundred fifty full-text articles were assessed against the eligibility criteria. Finally, 16 studies were included in the qualitative analysis, with a total of 16,692 patients, and 12 studies were included in the quantitative analysis. The characteristics of the studies are shown in Table I (characteristics of the included studies).

\section{Study and participant characteristics.}

Women were $97 \%$ of the sample $[1,4,5,9,11,12,24,27,28,30,31,32]$, and the median patient age at diagnosis was 57 years. The majority of participants were considered to be White (78\%) [4, 12, 25, 27, 33]. A total of 9,504 patients underwent surgery, and amongst these, 55\% 
underwent an axillary surgical approach. Only five studies included patients undergoing sentinel lymph node biopsy [1, 24, 25, 30, 32], and from these, one reported that $27 \%$ of the patients successfully underwent this procedure [24]. Mastectomy was the most prevalent surgery $[1,4,9,11,25-33]$.

In the surgery group, bone metastasis was more common than visceral metastasis [5, 8, 9, 24-33], and single organ metastasis was more frequent than multiple metastases [1, 5, 8, 25, 27-33]. No prospective studies were found with the primary aim of comparing survival data due to axillary management [12]. There was a report on the reduction of the risk of death by up to $40 \%$ with the axillary surgical approach [34].Complementary radiotherapy to surgery was performed on an average of $27 \%$ of patients $[1,4,9,24,25,26,27,28,29,31,32]$, with only two studies citing survival results related to this procedure [10, 28]. Treatment with chemotherapy was performed by an average of $75 \%$ of patients, with only three studies discriminating against the scheme based on anthracycline $[1,5,30]$, taxane $[1,27]$ and target therapy with trastuzumab $[9,30,31]$.

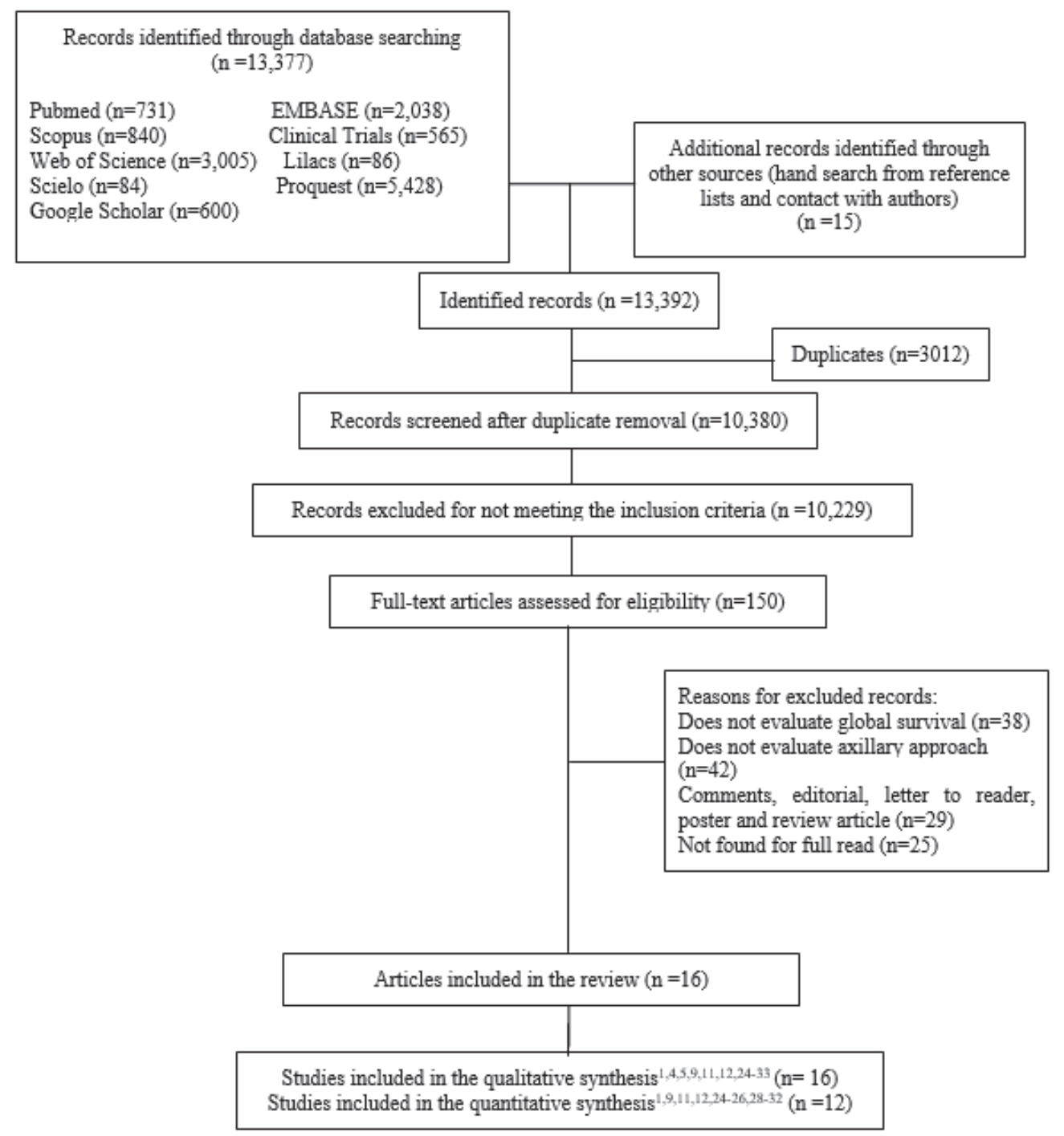

Figure 1. Flowchart of the study selection process. 
Table 1. Characteristics of the included studies.

\begin{tabular}{|c|c|c|c|c|c|c|c|c|c|}
\hline $\begin{array}{l}\text { Author, } \\
\text { publication } \\
\text { year }\end{array}$ & $\begin{array}{l}\text { Period of } \\
\text { enrolment }\end{array}$ & $\begin{array}{l}\text { Prospective } \\
\text { study design }\end{array}$ & Country & $\begin{array}{l}\text { Sample } \\
\text { size }(n)\end{array}$ & $\begin{array}{l}\text { Follow-up } \\
\text { (months) }\end{array}$ & $\begin{array}{c}\text { Axillary } \\
\text { and breast } \\
\text { surgery }(n)\end{array}$ & $\begin{array}{l}\text { Overall survival } \\
\text { axillary approach } \\
\text { (surgery } \times \text { not } \\
\text { surgery) }\end{array}$ & $\begin{array}{l}\text { Overall survival } \\
\text { breast surgery } \\
\text { (surgery } \times \text { not } \\
\text { surgery) }\end{array}$ & $\begin{array}{c}\text { Mortality } \\
\text { (surgery } \times \text { not } \\
\text { surgery) }\end{array}$ \\
\hline $\begin{array}{l}\text { Ruiterkamp } \\
\text { et al [29] }\end{array}$ & $1993-2004$ & No & Netherlands & 728 & 156 & $\begin{array}{l}\text { BS 288/728 } \\
/ / \text { ALND } \\
190 / 288\end{array}$ & $\begin{array}{l}\text { ALND tended } \\
\text { to have a better } \\
\text { overall survival } \\
\text { but only in the } \\
\text { first year } \\
p=0.35\end{array}$ & $\begin{array}{l}\mathrm{HR}=0.62 ; 95 \% \\
\mathrm{Cl} ; 0.51-0.76 \\
p<0.001 \\
31 \text { versus } 14 \\
\text { months } \\
5 \text {-year survival } \\
\text { rate } 24.5 \% \\
\text { versus } 13.1 \% \\
p<0.0001\end{array}$ & $\begin{array}{l}\text { Reduction of } \\
\text { mortality risk } \\
\sim 40 \% \\
\mathrm{HR}=0.66 ; \\
95 \% \mathrm{Cl} \\
0.55-0.80\end{array}$ \\
\hline $\begin{array}{l}\text { Mcguire } \\
\text { et al [27] }\end{array}$ & 1990-2007 & No & USA & 566 & 37 & $\begin{array}{l}\text { BS154/566// } \\
\text { ALND } \\
97 / 154\end{array}$ & $\begin{array}{l}\text { Nonsignificant } \\
\text { trend toward } \\
\text { ALND } 46 \% \\
\text { versus } 17 \% \\
p=0.26\end{array}$ & $\begin{array}{l}\text { OS rate } 33 \% \\
\text { versus } 20 \% \\
p=0.0012\end{array}$ & - \\
\hline $\begin{array}{l}\text { Neuman } \\
\text { et al [9] }\end{array}$ & $2000-2004$ & No & USA & 186 & 52 & $\begin{array}{l}\text { BS 69/186// } \\
\text { ALND 33/69 }\end{array}$ & - & $\begin{array}{l}\mathrm{HR}=0.71 ; 95 \% \\
\mathrm{Cl} ; 0.47-1.10 ; \\
p=0.10 \\
40 \text { versus } 33 \\
\text { months } \\
5 \text {-year survival } \\
\text { rate } 30 \%\end{array}$ & $\begin{array}{l}69 \% \text { died dur- } \\
\text { ing follow-up }\end{array}$ \\
\hline $\begin{array}{l}\text { Nguyen } \\
\text { et al [1] }\end{array}$ & $1996-2005$ & Yes & Canada & 733 & 22.8 & $\begin{array}{l}\text { BS } \\
318 / 733 / / \\
\text { ALND } \\
+ \text { SLND } \\
215 / 318\end{array}$ & $\begin{array}{l}\text { HR 1.36; 95\% Cl } \\
0.91-2.04 \\
\text { 5-year Kaplan- } \\
\text { Meier OS 24.1\% } \\
\text { versus } 17.5 \% \\
p=0.31\end{array}$ & $\begin{array}{l}\mathrm{HR}=0.78 ; 95 \% \\
\mathrm{Cl} ; 0.64-0.94 p \\
=0.009 \\
5 \text {-year Kaplan- } \\
\text { Meier OS } 21 \% \\
\text { versus } 14 \% \\
p<0.001\end{array}$ & - \\
\hline $\begin{array}{l}\text { Rashaan } \\
\text { et al [11] }\end{array}$ & 1989-2009 & No & Netherlands & 171 & - & $\begin{array}{l}\text { BS 59/171// } \\
\text { ALND 43/59 }\end{array}$ & - & $\begin{array}{l}\mathrm{HR}=0.9095 \% \\
\mathrm{Cl} 0.59-1.37 \\
p=0.05\end{array}$ & $\begin{array}{l}\text { Decreased } \\
\text { risk of death } \\
\text { with no } \\
\text { comorbidity } \\
\text { HR } 0.495 \% \\
\mathrm{Cl} 0.2-0.7 p \\
=0.002 \text { and } \\
\text { no medication } \\
\text { use } \mathrm{HR}=0.5 \\
95 \% \mathrm{Cl} \text {; } \\
0.2-0.8 \\
p=0.01\end{array}$ \\
\hline
\end{tabular}


Table 1. Characteristics of the included studies. (Continued)

\begin{tabular}{|c|c|c|c|c|c|c|c|c|c|}
\hline $\begin{array}{l}\text { Sofi et al } \\
\text { [33] }\end{array}$ & 1999-2009 & No & USA & 37 & - & $\begin{array}{l}\text { BS } 37 / / \\
\text { ALND } 37\end{array}$ & - & $\begin{array}{l}8.83 \text { versus } \\
(4.91+2.26) \\
\text { years } p=0.005\end{array}$ & - \\
\hline $\begin{array}{l}\text { Lang et al } \\
\text { [25] }\end{array}$ & 1997-2002 & No & USA & 208 & 74.2 & $\begin{array}{l}\text { BS 74/208 } \\
\text { // ALND or } \\
\text { SLND 39/74 }\end{array}$ & $\begin{array}{l}\text { No significant } \\
\text { trend toward } \\
\text { improved survival } \\
\text { to axillary pro- } \\
\text { cedure (SLND or } \\
\text { ALND) } p=0.06\end{array}$ & $\begin{array}{l}\mathrm{HR}=0.58,95 \\
\% \mathrm{Cl} 0.35-0.98 \\
p=0.04\end{array}$ & $\begin{array}{l}65 \% \text { died dur- } \\
\text { ing follow-up }\end{array}$ \\
\hline Elkhouly [5] & 2009-2011 & No & Egypt & 151 & - & $\begin{array}{l}\text { BS 61/151// } \\
\text { ALND 60/61 }\end{array}$ & - & $\begin{array}{l}39.10 \text { versus } \\
28.04 \text { months } \\
<p=0.001\end{array}$ & $\begin{array}{l}89 \% \times 98 \% p \\
=0.156 \\
45 \% \text { died dur- } \\
\text { ing follow-up }\end{array}$ \\
\hline $\begin{array}{l}\text { Rhu et al } \\
\text { [26] }\end{array}$ & $1995-2011$ & No & Korea & 262 & 29.6 & $\begin{array}{l}\text { BS 40/262// } \\
\text { ALND 33/40 }\end{array}$ & - & $\begin{array}{l}\text { HR 0.51; } 95 \% \\
\mathrm{Cl} ; 0.33-0.80) \\
p<0.01 \\
\text { Global mean } \\
\text { survival rate } \\
55 \text { months (Cl } \\
41.81-68.25)\end{array}$ & $\begin{array}{l}65 \% \text { versus } \\
69 \% p=0.58\end{array}$ \\
\hline $\begin{array}{l}\text { Quinn et al } \\
\text { [24] }\end{array}$ & 2006-2012 & No & Ireland & 109 & 24 & $\begin{array}{l}\text { BS 52/109// } \\
\text { ALND } 45 \text { and } \\
\text { SLND } 14\end{array}$ & $\begin{array}{l}\text { SLNB } 20.2 \text { and } \\
\text { ALND } 34.8 \\
\text { months } p=0.363\end{array}$ & $\begin{array}{l}\mathrm{HR}=1.094 ; 95 \% \\
\mathrm{Cl} ; 0.442- \\
6.128 p=0.013 \\
\text { Mean OS } 29.5 \\
\text { months } \\
35.8 \text { versus } \\
20.2 \text { months } \\
p=0.003\end{array}$ & - \\
\hline $\begin{array}{l}\text { Badwe et al } \\
\text { [31] }\end{array}$ & 2001-2012 & Yes & India & 350 & 23 & $\begin{array}{l}\text { BS } 165 \\
\text { ALND } 165\end{array}$ & $\begin{array}{l}\text { HR } 1.94 \text { (0.81 - } \\
1.34) p=0,79\end{array}$ & - & $\begin{array}{l}50.2 \% \text { versus } \\
49.8 \%\end{array}$ \\
\hline $\begin{array}{l}\text { Aljohani } \\
\text { et al [28] }\end{array}$ & $2000-2012$ & No & Saudi Arabia & 678 & 41 & $\begin{array}{l}\text { BS 412/678 } \\
/ / \text { ALND } \\
264 / 678\end{array}$ & - & $\begin{array}{l}\mathrm{HR} 0.6095 \% \mathrm{Cl} \\
0.48-0.873 p= \\
0.0003 \\
5 \text {-year survival } \\
\text { rate } 34 \% \text { versus } \\
14 \% / / 41 \text { ver- } \\
\text { sus } 27 \text { months } \\
p<0.0029\end{array}$ & $\begin{array}{l}52 \% \text { died } \\
\text { during } \\
\text { follow-up }\end{array}$ \\
\hline $\begin{array}{l}\text { Wuet al } \\
{[12]}\end{array}$ & $1990-2010$ & No & China & 11.645 & - & $\begin{array}{l}\text { BS - // ALND } \\
7358 / \\
11645\end{array}$ & $\begin{array}{l}\text { OS HR =0.630; } \\
95 \% \mathrm{Cl} \\
0.60-0.66 ; \\
p<0.001 \\
\text { BCSS HR = } \\
0.633 ; 95 \% \mathrm{Cl} ; \\
0.60-0.67 ; \\
p<0.001\end{array}$ & - & - \\
\hline
\end{tabular}


Table 1. Characteristics of the included studies. (Continued)

\begin{tabular}{|c|c|c|c|c|c|c|c|c|c|}
\hline $\begin{array}{l}\text { Muzaffar et } \\
\text { al [4] }\end{array}$ & 1988-2011 & No & USA & 439 & 48 & $\begin{array}{l}\text { BS 222/439 } \\
/ / \text { ALND } \\
117 / 222\end{array}$ & - & $\begin{array}{l}\text { Median OS } \\
29 \text { versus } 11 \\
\text { months } \\
\text { Not surgery } \\
\text { diminished sur- } \\
\text { vival HR = 1.81; } \\
95 \% 1.42-2.31 \text {; } \\
p<0.001\end{array}$ & - \\
\hline $\begin{array}{l}\text { Soran et al } \\
\text { [30] }\end{array}$ & $2000-2012$ & Yes & Turkey & 274 & 54.5 & $\begin{array}{l}\text { BS } 138 \\
\text { SLND } 23 \\
(17 \%) \\
\text { ALND } 128 \\
(92.8 \%)\end{array}$ & $\begin{array}{l}\text { HR } 0.63(0.44- \\
0.90) p=0.008\end{array}$ & - & $\begin{array}{l}55 \% \text { versus } \\
74 \% \\
34 \% \text { lower in } \\
\text { the surgery } \\
\text { group }\end{array}$ \\
\hline $\begin{array}{l}\text { Fitzal et al } \\
\text { [32] }\end{array}$ & 2011-2015 & Yes & Austria & 90 & 37.5 & $\begin{array}{l}\text { BS } 42 \\
\text { SLND } 3 \\
\text { (7.1\%) } \\
\text { EA 39 (93\%) }\end{array}$ & $\begin{array}{l}\text { HR } 0.691(0.358 \\
-1.333) \\
p=0.267\end{array}$ & - & - \\
\hline
\end{tabular}

BS - breast surgery,

ALND - axillary lymph node dissection,

SLND - sentinel lymph node biopsy,

HR - hazard ratio,

$95 \% \mathrm{Cl}-95 \%$ confidence interval,

OS - overall survival,

BCSS - breast cancer-specific survival.

It is noteworthy that the majority who underwent chemotherapy was in the surgery group, and the non-surgery group received hormone therapy more frequently. Systemic treatment regimens were diverse and carried out at different times, with more effective drugs used in the most current studies, which has an impact on survival. Radiotherapy was not performed and was mentioned uniformly in the research.

\section{Quality assessment}

Hence, we chose to direct the information to respond to the purpose of the review, avoiding excesses and unclear initial data. The quality assessment for each study is shown in Table II (risk of bias assessed by the Joanna Briggs Institute's critical appraisal checklist for cohort studies) and III (risk of bias assessed by the Joanna Briggs Institute's critical appraisal checklist for randomised controlled trials). All studies seemed to have good methodological quality, with a mean of eight 'yes' answers.

\section{Quality of evidence}

According to the evaluation of the Grade System [19], the classification of the evidence was of very low quality due to the high inconsistency across the studies, statistical inaccuracies and possibility of selection bias.

\section{Sensitivity analysis}

The sensitivity analysis considered two studies' outliers from the meta-analysis and were disregarded from the analysis which did not affect the results. 
Table 2. Risk of bias assessed by Joanna Briggs Institute's critical appraisal checklist for cohort studies.

\begin{tabular}{|c|c|c|c|c|c|c|c|c|c|c|c|c|c|}
\hline Questions & $\begin{array}{l}\text { Ruiterkamp } \\
\text { et al [29] }\end{array}$ & $\begin{array}{l}\text { McGuire } \\
\text { et al } \\
\text { [27] }\end{array}$ & $\begin{array}{l}\text { Neuman } \\
\text { et al [9] }\end{array}$ & $\begin{array}{l}\text { Nguyen } \\
\text { et al [1] }\end{array}$ & $\begin{array}{c}\text { Rashaan } \\
\text { et al } \\
{[11]}\end{array}$ & $\begin{array}{l}\text { Sofi et } \\
\text { al [33] }\end{array}$ & $\begin{array}{l}\text { Lang } \\
\text { et al } \\
{[25]}\end{array}$ & $\begin{array}{c}\text { Elkhouly } \\
\text { [5] }\end{array}$ & $\begin{array}{l}\text { Rhu J } \\
\text { et al } \\
{[26]}\end{array}$ & $\begin{array}{l}\text { Quinn } \\
\text { et al } \\
{[24]}\end{array}$ & $\begin{array}{l}\text { Aljohani } \\
\text { et al } \\
{[28]}\end{array}$ & $\begin{array}{l}\mathrm{Wu} \\
\text { et al } \\
{[12]}\end{array}$ & $\begin{array}{c}\text { Muzaffar } \\
\text { et al [4] }\end{array}$ \\
\hline $\begin{array}{l}\text { 1. Were the two } \\
\text { groups similar and } \\
\text { recruited from the } \\
\text { same population? }\end{array}$ & $U$ & $\mathrm{U}$ & $\mathrm{Y}$ & $Y$ & $N$ & $\mathrm{~N}$ & $\mathrm{Y}$ & $\mathrm{N}$ & $\mathrm{Y}$ & $\mathrm{Y}$ & $\mathrm{N}$ & $\mathrm{Y}$ & $\mathrm{N}$ \\
\hline $\begin{array}{l}\text { 2. Were the expo- } \\
\text { sures measured simi- } \\
\text { larly to assign people } \\
\text { to both exposed and } \\
\text { unexposed groups? }\end{array}$ & $\mathrm{N}$ & $\mathrm{Y}$ & $\mathrm{Y}$ & $U$ & $\mathrm{~N}$ & $\mathrm{~N}$ & $U$ & $\mathrm{~N}$ & $U$ & $\mathrm{Y}$ & $\mathrm{N}$ & $\mathrm{N}$ & $U$ \\
\hline $\begin{array}{l}\text { 3. Was the exposure } \\
\text { measured in a valid } \\
\text { and reliable way? }\end{array}$ & $\mathrm{Y}$ & $Y$ & $\mathrm{Y}$ & $\mathrm{Y}$ & $\mathrm{N}$ & $\mathrm{Y}$ & $Y$ & $U$ & $\mathrm{Y}$ & $Y$ & $\mathrm{Y}$ & $Y$ & $\mathrm{Y}$ \\
\hline $\begin{array}{l}\text { 4. Were confounding } \\
\text { factors identified? }\end{array}$ & $\mathrm{Y}$ & $\mathrm{Y}$ & $\mathrm{Y}$ & $\mathrm{Y}$ & $\mathrm{Y}$ & $\mathrm{Y}$ & $Y$ & $\mathrm{Y}$ & $\mathrm{Y}$ & $\mathrm{Y}$ & $\mathrm{Y}$ & $Y$ & $\mathrm{Y}$ \\
\hline $\begin{array}{l}\text { 5. Were strategies to } \\
\text { address confounding } \\
\text { factors stated? }\end{array}$ & $\mathrm{Y}$ & $\mathrm{N}$ & $\mathrm{Y}$ & $\mathrm{Y}$ & $Y$ & $\mathrm{Y}$ & $Y$ & $\mathrm{Y}$ & $\mathrm{Y}$ & $\mathrm{Y}$ & $U$ & $Y$ & Y \\
\hline $\begin{array}{l}\text { 6. Were the groups/ } \\
\text { participants free of } \\
\text { the outcome at the } \\
\text { start of the study (or } \\
\text { at the moment of } \\
\text { exposure)? }\end{array}$ & $\mathrm{Y}$ & $\mathrm{Y}$ & $\mathrm{Y}$ & $\mathrm{Y}$ & $\mathrm{Y}$ & $\mathrm{Y}$ & $\mathrm{Y}$ & $Y$ & $\mathrm{Y}$ & $\mathrm{Y}$ & $\mathrm{Y}$ & $\mathrm{Y}$ & $\mathrm{Y}$ \\
\hline $\begin{array}{l}\text { 7. Were the out- } \\
\text { comes measured in } \\
\text { a valid and reliable } \\
\text { way? }\end{array}$ & $\mathrm{Y}$ & $\mathrm{Y}$ & $\mathrm{Y}$ & $\mathrm{Y}$ & $Y$ & $\mathrm{Y}$ & $Y$ & $U$ & $\mathrm{Y}$ & $\mathrm{U}$ & $Y$ & $Y$ & $\mathrm{U}$ \\
\hline $\begin{array}{l}\text { 8. Was the follow-up } \\
\text { time reported and } \\
\text { sufficient to be long } \\
\text { enough for outcomes } \\
\text { to occur? }\end{array}$ & Y & $Y$ & $\mathrm{Y}$ & $\mathrm{N}$ & $\mathrm{N}$ & Y & Y & Y & $\mathrm{Y}$ & $Y$ & $Y$ & $Y$ & Y \\
\hline $\begin{array}{l}\text { 9. Was follow-up } \\
\text { complete, and if not, } \\
\text { were the reasons to } \\
\text { loss to follow-up de- } \\
\text { scribed and explored? }\end{array}$ & $\mathrm{Y}$ & $\mathrm{N}$ & $\mathrm{N}$ & $\mathrm{N}$ & $\mathrm{N}$ & $\mathrm{Y}$ & $\mathrm{N}$ & $\mathrm{N}$ & $\mathrm{N}$ & $\mathrm{N}$ & $\mathrm{N}$ & $\mathrm{N}$ & $\mathrm{N}$ \\
\hline $\begin{array}{l}\text { 10. Were strategies } \\
\text { to address incomplete } \\
\text { follow-up utilised? }\end{array}$ & $\mathrm{Y}$ & $\mathrm{N}$ & $\mathrm{Y}$ & $\mathrm{Y}$ & $Y$ & $Y$ & $\mathrm{Y}$ & $Y$ & $\mathrm{Y}$ & $\mathrm{N}$ & $Y$ & $Y$ & $Y$ \\
\hline $\begin{array}{l}\text { 11. Was appropriate } \\
\text { statistical analysis } \\
\text { used? }\end{array}$ & $\mathrm{Y}$ & $\mathrm{N}$ & $\mathrm{Y}$ & $\mathrm{Y}$ & $Y$ & $Y$ & $Y$ & $Y$ & $\mathrm{Y}$ & $\mathrm{Y}$ & $\mathrm{Y}$ & $Y$ & $Y$ \\
\hline $\begin{array}{l}\text { Total number of ' } y \text { ' } \\
\text { answers }\end{array}$ & 9 & 6 & 10 & 8 & 6 & 9 & 9 & 10 & 6 & 8 & 9 & 7 & 7 \\
\hline
\end{tabular}

Note: $\mathrm{Y}=$ yes; $\mathrm{N}=\mathrm{No} ; \mathrm{U}=$ unclear. 
Table 3. Risk of bias assessed by the Joanna Briggs Institute's critical appraisal checklist for randomised controlled trials.

\begin{tabular}{|c|c|c|c|}
\hline Questions & Badwe et al [31] & Soran et al [30] & Fitzal el al. [32] \\
\hline 1. Was true randomisation used for the assignment of participants to treatment groups? & Y & Y & $\mathrm{Y}$ \\
\hline 2. Was allocation to treatment groups concealed? & Y & Y & y \\
\hline 3. Were treatment groups similar at the baseline? & Y & Y & $\mathrm{N}$ \\
\hline 4. Were participants blind to treatment assignment? & $\mathrm{N}$ & $\mathrm{N}$ & $\mathrm{N}$ \\
\hline 5. Were those delivering treatment blind to treatment assignment? & $\mathrm{N}$ & $\mathrm{N}$ & $\mathrm{N}$ \\
\hline 6. Were outcomes assessors blind to treatment assignment? & $\mathrm{N}$ & $\mathrm{N}$ & $\mathrm{N}$ \\
\hline 7. Were treatment groups treated identically other than the intervention of interest? & Y & Y & Y \\
\hline $\begin{array}{l}\text { 8. Was follow-up complete, and if not, were differences between groups in terms of their } \\
\text { follow-up adequately described and analysed? }\end{array}$ & Y & Y & $\mathrm{N}$ \\
\hline 9. Were participants analysed in the group to which they were randomised? & Y & Y & Y \\
\hline 10. Were outcomes measured in the same way for treatment groups? & Y & Y & $\mathrm{Y}$ \\
\hline 11. Were outcomes measured in a reliable way? & Y & Y & Y \\
\hline 12. Was appropriate statistical analysis used? & Y & $\mathrm{Y}$ & $\mathrm{Y}$ \\
\hline $\begin{array}{l}\text { 13. Was the trial design appropriate and any deviations from the standard RCT design } \\
\text { (individual randomisation and parallel groups) accounted for in the conduct and analysis of } \\
\text { the trial? }\end{array}$ & Y & Y & Y \\
\hline Total number of ' $y$ ' answers & 10 & 10 & 8 \\
\hline
\end{tabular}

Note: $\mathrm{Y}=$ yes; $\mathrm{N}=\mathrm{No} ; \mathrm{U}=$ unclear

\section{Meta-analyses for overall survival}

There was no association between axillary surgical resection and survival ( $\mathrm{HR} 0.82 ; 95 \% \mathrm{Cl}, 0.60-1.13$ ), and a high heterogeneity between studies was observed, with an $l^{2}=85.1 \%$ and $p<0.001$ [1, 12, 30, 31, 32] (Figure 2). Regarding breast surgical resection [1, 9, 11, 24, 25, $26,28,29]$, there was a protective effect related to survival (HR $0.70 ; 95 \% \mathrm{Cl}, 0.60-0.82)$ with a moderate and significant heterogeneity $\left(I^{2}=40.5 \%, p=0.098\right)$ (Figure 3).

\section{Risk of bias}

We used Cochrane's tool for assessing the risk of bias, and the result revealed that the studies were at risk of low or uncertain bias as shown in Figure 4.

\section{Discussion}

The available evidence indicated that the axillary surgical approach in metastatic breast cancer was not associated with an increase in overall survival. It was observed that the majority of participants with breast cancer underwent an axillary surgical technique. However, most of the physicians used this treatment preferably for women who presented with small tumours, and it is suspected that there may be great variability amongst women with metastatic breast cancer due to different stages of the disease and access to systemic treatment, which may impact the survival of the patients affected by the neoplasia. 


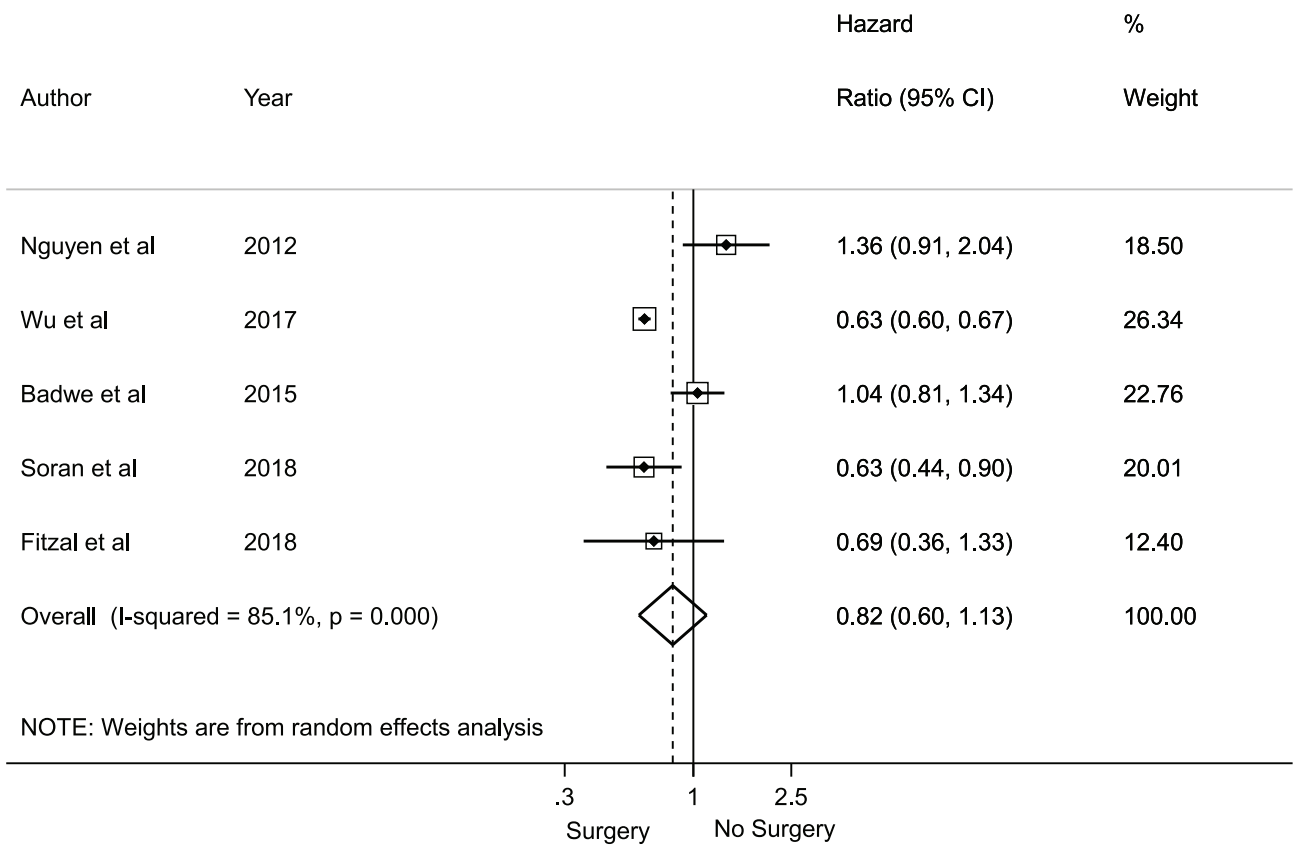

Figure 2. Meta-analysis for axillary approach and overall survival.

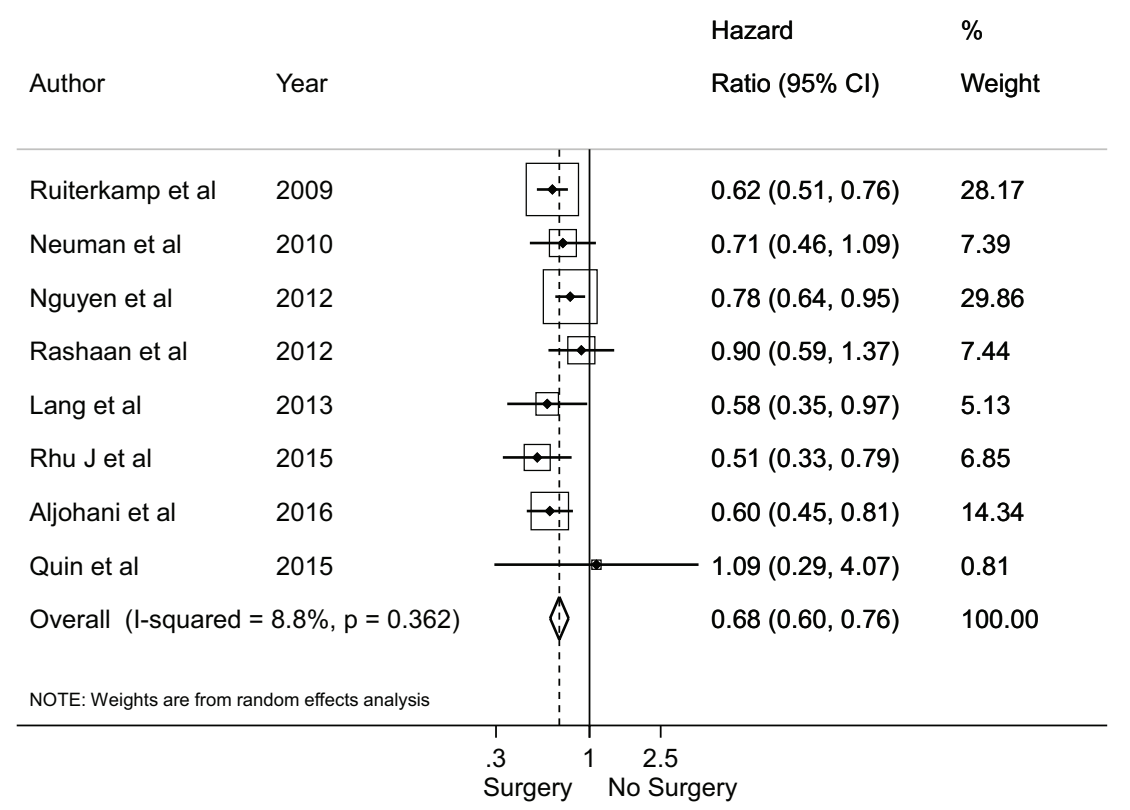

Figure 3. Meta-analysis for breast surgery and overall survival. 


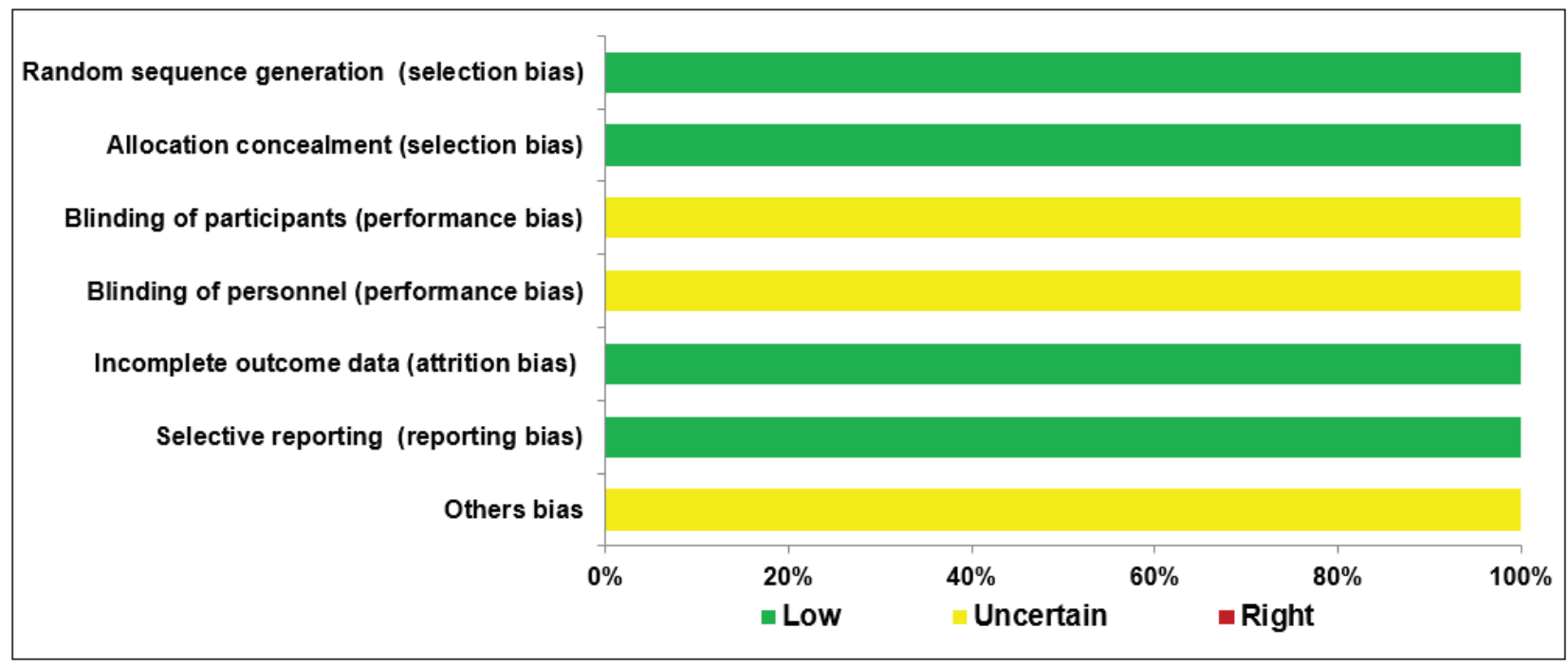

Figure 4. Cochrane's risk of bias tool.

Moreover, it was possible to determine, as a secondary result of this systematic review, an association between the surgical approach and an increase in overall survival. Mastectomy was the predominant surgical option, and the use of other techniques that would allow for breast reconstruction was not reported. There is a previously published systematic review that evaluated the relationship between breast surgery in women with metastasis and overall survival [35], but there are no reports on the influence of the axillary surgical approach on the outcome investigated.

Cohort studies, which were considered to be of good methodological quality, were included in this study [1, 12]; however, there are few longitudinal studies with robust data that evaluated the relationship between overall survival and local control of the disease after the use of axillary surgery. Omitting primary tumour surgery may reduce the overall survival of these patients [4, 29], but the relationship between the surgical technique and this outcome was not evaluated in any studies.

In addition, some authors have stated that women younger than 50 years, with smaller tumours (T1/T2), a lower volume of metastatic disease and those without HER-2/neu amplification and fewer comorbidities are more likely to be treated with aggressive multimodal therapy in the form of surgical excision of the primary tumour and local radiotherapy and systemic treatment $[9,11,31,32,36]$. However, it has been perceived that there is insufficient evidence to strengthen the use of these criteria as indications for axillary surgical treatment of metastatic breast cancer.

Two important randomised trials attempted to assess the effect on overall survival of locoregional treatment on the primary tumour in the breast and armpit compared to non-treatment in metastatic breast cancer [30, 31]. Both studies concluded that there is no evidence to suggest that locoregional treatment of the primary tumour affects overall survival in patients with metastatic breast cancer at the initial presentation. However, in the Turkish study, Soran 2018 showed benefit in terms of overall survival in subgroup analyses in selected patients with positive hormone receptor, negative HER-2, women under 55 years old and single bone metastasis [30].

The women included in the Indian study conducted by Badwe 2015 had more advanced diseases, more sites of metastasis and were mostly symptomatic, and only $8.5 \%$ of patients with HER2 tumour overexpression received anti-HER2 therapy [31]. These factors may reflect the inefficiency of the country's health and screening programmes. However, it can interfere with the evaluation of the intervention [35]. In addition, the study excluded patients who did not respond to systemic treatment, i.e., patients with a worse prognosis. In the Turkish study, patients had fewer simultaneous metastasis sites, with better access to treatment with Trastuzumab for all patients with tumour overexpression of HER2. These aspects highlighted interfere in the overall survival result and may have contributed to a better result in subgroup analysis. 
The systematic review of Tosello 2018 mapped randomised clinical trials, and it is not possible to do a meta-analysis because only two studies (Turkish and Indian) were included. The conclusion is that it is uncertain whether breast surgery improves overall survival since the quality of the evidence was assessed as very low [35]. It is known that, in the absence of randomised clinical trials, observational studies are considered as an alternative to initial evidence on the subject [37]. Still, it is delicate to carry out randomised clinical trials in vulnerable population groups, such as women with metastatic cancer. For this reason, there may be few randomised clinical trials on the topic.

Another prospective study with the same objective as the previous ones did not show any benefit in the overall survival for locoregional treatment in metastatic breast cancer, but the trial has stopped early due to insufficient recruitment [32]. The groups were well balanced as to the type of systemic treatment; however, in the surgery group, patients had more advanced tumours, both in the breast and in the armpit, which may have influenced the prognosis and, consequently, survival.

Locoregional treatment for metastatic cancer is hypothesised to improve survival based on retrospective analyses, but randomised studies provide conflicting data. Retrospective studies have peculiarities as women who were submitted to surgery belonged to younger groups, with smaller tumours, being a positive hormonal receptor, and presenting a lower volume of metastatic disease. The ASCO report (summary LB2A) of the randomised phase III trial E2108 suggests that early local therapy does not extend survival in patients with newly diagnosed metastatic breast cancer and has no benefit in terms of quality of life [38]. Locoregional treatment in this scenario can be considered when the systemic disease is well controlled, but the locoregional disease is progressing. Some data from this study are still pending and may help to clarify many issues in the future.

What differentiates the results of this review from other studies $[30,31,35,38]$ is the type of study employed, possibly being the first systematic review that used retrospective studies, due to the scarcity of randomised clinical trials on the topic [38].

From a methodological point of view, a randomised clinical trial is not an absolute truth to ensure that evidence is effective and applicable to the entire population. To elucidate these questions, systematic review is recommended, which was the objective of the present study.

Regarding the limitations, the possibility of selection bias of the participants in the original research is raised since aspects related to the use of systemic therapy can interfere with the evolution of the disease, in the decision-making about the surgical intervention and in the allocation of these women to the group treated with axillary surgery; that is, only women with a better prognosis may have been referred for surgery. In addition, the sample representation is another item that should be considered as a limitation of the original research. Although a broad search was conducted in several databases, there was only a limited amount of evidence available on the subject. Thus, it was not possible to apply other more robust analytical techniques such as evaluation of publication bias, Egger testing, subgroup analysis and metaregressions.

A possible source of heterogeneity may have been the inclusion of methodologically different studies, diversity in the use of treatment protocols, insufficient registration of information in the original research, regional differences and the use of combined surgical techniques (breast and axillary approaches). Through the sensitivity analysis, it was possible to identify the major factors that influenced the high statistical heterogeneity.

From the perspective of reducing bias, a search was made of the grey literature, and contact was made with the authors of the published articles about missing data. Nevertheless, caution should be exercised in the interpretation of the findings since the data may present distorted results. The Grade assessment indicated a very poor quality of evidence due to the risk of bias, inaccuracy and inconsistency. Thus, the results of this review should be carefully evaluated before being considered as a recommendation.

Regarding strengths, the use of validated instruments for the sensitive evaluation of the analysis of search strategies, measurement of methodological quality and writing of systematic reviews, such as PRESS, Joanna Briggs, MOOSE and Prisma, was employed. Another positive aspect was the selection of cohorts, with a secure record of the intervention and outcome, minimising the possibility of information bias. 


\section{Conclusion}

As far as we know, this is the first systematic review on this topic, and we observed that there is no association between an axillary surgical approach and increased overall survival in patients with metastatic breast cancer. Thus, it is necessary to carry out additional longitudinal studies on this topic, with increased methodological robustness. The indications for the surgical approach in the metastatic context should be individualised considering the characteristics of the individual and the response to systemic treatment. The true impact of locoregional therapies on long-term outcomes remains unknown.

\section{Conflicts of interest}

The authors state that they do not have any conflicts of interest.

\section{Funding statement}

There are no sources of support for the reported work, including grants, equipment and medications, and no funding was received for this work from any organisation.

\section{References}

1. Nguyen DH, Truong PT, and Alexander C, et al (2012) Can locoregional treatment of the primary tumor improve outcomes for women with stage IV breast cancer at diagnosis? Int J Radiat Oncol Biol Phys 84(1) 39-45 https://doi.org/10.1016/j.ijrobp.2011.11.046 PMID: 22330986

2. Pagani O, Senkus E, and Wood W, et al (2010) International guidelines for management of metastatic breast cancer: can metastatic breast cancer be cured? J Natl Cancer Inst 102(7) 456-463 https://doi.org/10.1093/jnci/djq029 PMID: 20220104 PMCID: 3298957

3. Cardoso F, Costa A, and Senkus E, et al (2017) 3rd ESO-ESMO international consensus guidelines for advanced breast cancer (ABC 3) Ann Oncol 28(1) 16-33 https://doi.org/10.1093/annonc/mdw544 PMID: 28177437 PMCID: 5378224

4. Muzaffar M, Kachare S, and Vohra N. (2017) Impact of primary tumor surgery in stage IV male breast cancer Clin Breast Cancer 17(3) e143-e149 https://doi.org/10.1016/j.clbc.2016.11.001

5. Elkhouly EA, Tawfik EA, and ELsisy AA (2014) Impact of primary tumor resection on response and survival in metastatic breast cancer patients Life Sci J 11(7) 276-285

6. Petrelli F and Barni S (2012) Surgery of primary tumors in stage IV breast cancer: an updated meta-analysis of published studies with meta-regression Med Oncol 29(5) 3282-3290 https://doi.org/10.1007/s12032-012-0310-0 PMID: 22843291

7. Headon $\mathrm{H}$, Wazir $\mathrm{U}$, and Kasem A, et al (2016) Surgical treatment of the primary tumour improves the overall survival in patients with metastatic breast cancer: a systematic review and meta-analysis Mol Clin Oncol 4(5) 863-867 https://doi.org/10.3892/mco.2016.778 PMID: 27123297 PMCID: 4840567

8. Anula J, Sánchez Andújar B, and Machuca Chiriboga P, et al (2015) Surgical treatment of the primary tumor in stage IV breast cancer Cir Esp 93(6) 375-380

9. Neuman HB, Morrogh M, and Gonen M, et al (2010) Stage IV breast cancer in the era of targeted therapy: does surgery of the primary tumor matter? Cancer 116(5) 1226-1233 https://doi.org/10.1002/cncr.24873 PMID: 20101736 PMCID: 4505547 
10. Ruiterkamp J, Voogd AC, and Bosscha K, et al (2010) Impact of breast surgery on survival in patients with distant metastases at initial presentation: a systematic review of the literature Breast Cancer Res Treat 120(1) 9-16 https://doi.org/10.1007/s10549-009-0670-0

11. Rashaan ZM, Bastiaannet E, and Portielje JEA, et al (2012) Surgery in metastatic breast cancer: patients with a favorable profile seem to have the most benefit from surgery Eur J Surg Oncol 38(1) 52-56 https://doi.org/10.1016/j.ejso.2011.10.004

12. Wu SG, Li FY, and Chen Y, et al (2017) Therapeutic role of axillary lymph node dissection in patients with stage IV breast cancer: a population-based analysis J Cancer Res Clin Oncol 143(3) 467-474 https://doi.org/10.1007/s00432-016-2295-0

13. Stroup DF, Berlin JA, and Morton SC, et al (2000) Meta-analysis of observational studies in epidemiology: a proposal for reporting. Meta-analysis of observational studies in epidemiology (MOOSE) group JAMA 283(15) 2008-2012 https://doi.org/10.1001/ jama.283.15.2008 PMID: 10789670

14. Moher D, Liberati A, and Tetzlaff J, et al (2009) Preferred reporting items for systematic reviews and meta-analyses: the PRISMA statement PLoS Med 6(7) e1000097 https://doi.org/10.1371/journal.pmed.1000097 PMID: 19621072 PMCID: 2707599

15. McGowan J, Sampson M, and Salzwedel DM, et al (2016) PRESS peer review of electronic search strategies: 2015 guideline statement J Clin Epidemiol 7540 https://doi.org/10.1016/j.jclinepi.2016.01.021 PMID: 27005575

16. JBI. (2017). JBI Critical Appraisal Checklist for Cohort Studies (Australia: Joanna Briggs Institute).

17. JBI. (2017) JBI Critical Appraisal Checklist for Randomized Controlled Trials (Australia: Joanna Briggs Institute)

18. Balshem H, Helfand M, and Schünemann HJ, et al (2011) GRADE guidelines: 3. Rating the quality of evidence J Clin Epidemiol 64 401-406. https://doi.org/10.1016/j.jclinepi.2010.07.015 PMID: 21208779

19. GRADEpro 2014 [Computer program] GRADEpro GDT: GRADEpro Guideline Development Tool (McMaster University developed by Evidence Prime, Inc) [www.gradepro.org] [http://www.gradepro.org] 2015

20. Higgins JPT and Green S (editors) (2011) Cochrane Handbook for Systematic Reviews of Interventions Version 5.1.0 [updated March 2011] The Cochrane Collaboration [http://handbook.cochrane.org]

21. Sterne JAC and Kirkwood BR (2003) Essential medical statistics 2nd edn (Hoboken: Blackwell Publishing)

22. Higgins JP, Thompson SG, and Deeks JJ, et al (2003) Measuring inconsistency in meta-analyses BMJ 327(7414) 557-560 https://doi. org/10.1136/bmj.327.7414.557 PMID: 12958120 PMCID: 192859

23. DerSimonian R and Laird N (2015) Meta-analysis in clinical trials revisited Contemp Clin Trials 45(Pt A) 139-145 https://doi.org/10.1016/j. cct.2015.09.002 PMID: 26343745 PMCID: 4639420

24. Quinn EM, Kealy R, and O'Meara S, et al (2015) Is there a role for locoregional surgery in stage IV breast cancer? Breast 24(1) 32-37 https://doi.org/10.1016/j.breast.2014.10.009

25. Lang JE, Tereffe W, and Mitchell MP, et al (2013) Primary tumor extirpation in breast cancer patients who present with stage IV disease is associated with improved survival Ann Surg Oncol 20(6) 1893-1899 https://doi.org/10.1245/s10434-012-2844-y PMID: 23306905 PMCID: 4353581

26. Rhu J, Lee SK, and Kil WH, et al (2015) Surgery of primary tumour has survival benefit in metastatic breast cancer with single-organ metastasis, especially bone ANZ J Surg 85(4) 240-244 https://doi.org/10.1111/ans.12548 PMID: 25996008

27. McGuire KP, Eisen S, and Rodriguez A, et al (2009) Factors associated with improved outcome after surgery in metastatic breast cancer patients Am J Surg 198(4) 511-515 https://doi.org/10.1016/j.amjsurg.2009.06.011 PMID: 19800458

28. AlJohani B, AIMalik O, and Anwar E, et al (2016) Impact of surgery on survival in stage IV breast cance. Breast J 22(6) 678-682 https:// doi.org/10.1111/tbj.12662 PMID: 27564998 
29. Ruiterkamp J, Ernst MF, and van de Poll-Franse LV, et al (2009) Surgical resection of the primary tumour is associated with improved survival in patients with distant metastatic breast cancer at diagnosis Eur J Surg Oncol 35(11) 1146-1151 https://doi.org/10.1016/j. ejso.2009.03.012 PMID: 19398188

30. Soran A, Ozmen V, and Ozbas S, et al (2018) Randomized trial comparing resection of primary tumor with no surgery in stage IV breast cancer at presentation: protocol MF07-01. Ann Surg Oncol 25(11) 3141-3149 [Epub ahead of print] https://doi.org/10.1245/s10434018-6494-6 PMID: 29777404

31. Badwe R, Hawaldar R, and Nair N, et al (2015) Locoregional treatment versus no treatment of the primary tumour in metastatic breast cancer: an open-label randomised controlled trial Lancet Oncol 16(13) 1380-1388 Epub 2015 Sep 9 https://doi.org/10.1016/S14702045(15)00135-7 PMID: 26363985

32. Fitzal F, Bjelic-Radisic V, and Knauer M, et al (2018) Impact of breast surgery in primary metastasized breast cancer. Outcomes of the prospective randomized phase III ABCSG-28 POSYTIVE trial Ann Surg 269(6) 1163-1169

33. Sofi AA, Mohamed I, and Koumaya M, et al (2013) Local therapy in metastatic breast cancer is associated with improved survival Am J Ther 20(5) 487-492 https://doi.org/10.1097/MJT.0b013e31822119c5

34. Rayter Z (2012) Surgery for stage IV breast cancer Eur J Surg Oncol 38(5) https://doi.org/10.1016/j.ejso.2012.02.081

35. Tosello G, Torloni MR, and Mota BS, et al (2018) Breast surgery for metastatic breast cancer (Review) Cochrane Database Syst Rev 153

36. Ly BH, Nguyen NP, and Vinh-Hung V, et al (2010) Loco-regional treatment in metastatic breast cancer patients: is there a survival benefit? Breast Cancer Res Treat 119(3) 537-545 https://doi.org/10.1007/s10549-009-0610-z

37. Brasil (2014) Ministério da Saúde. Secretaria de Ciência, Tecnologia e Insumos Estratégicos (Departamento de Ciência e Tecnologia. Diretrizes metodológicas: Sistema GRADE - Manual de graduação da qualidade da evidência e força de recomendação para tomada de decisão em saúde/Ministério da Saúde, Secretaria de Ciência, Tecnologia e Insumos Estratégicos, Departamento de Ciência e Tecnologia. - Brasília : Ministério da Saúde) 72 p

38. Khan SA, Zhao A, and Solin LJ, et al (2020) A randomized phase III trial of systemic therapy plus early local therapy versus systemic therapy alone in womem with de novo stage IV breast cancer: a trial of the ECOG-ACRIN Research Group (E2108) J Clin Oncol 38 https://doi.org/10.1200/JCO.2020.38.18_suppl.LBA2 


\section{Appendix}

Appendix S1. MOOSE checklist for meta-analyses of observational studies.

\begin{tabular}{|c|c|c|}
\hline Item no & Recommendation & $\begin{array}{l}\text { Reported on } \\
\text { page no }\end{array}$ \\
\hline \multicolumn{3}{|c|}{ Reporting of background should include } \\
\hline 1 & Problem definition & 4 \\
\hline 2 & Hypothesis statement & 4 \\
\hline 3 & Description of study outcome(s) & 4 \\
\hline 4 & Type of exposure or intervention used & 4 \\
\hline 5 & Type of study designs used & 4 \\
\hline 6 & Study population & 4 \\
\hline \multicolumn{3}{|c|}{ Reporting of search strategy should include } \\
\hline 7 & Qualifications of searchers (e.g., librarians and investigators) & 1 \\
\hline 8 & Search strategy, including time period included in the synthesis and keywords & $3 ; 4 ; 5$ \\
\hline 9 & Effort to include all available studies, including contact with authors & $4 ; 5$ \\
\hline 10 & Databases and registries searched & 5 \\
\hline 11 & Search software used, name and version, including special features used (e.g., explosion) & 7 \\
\hline 12 & Use of hand searching (e.g., reference lists of obtained articles) & 5 \\
\hline 13 & List of citations located and those excluded, including justification & 4 \\
\hline 14 & Method of addressing articles published in languages other than English & 5 \\
\hline 15 & Method of handling abstracts and unpublished studies & 5 \\
\hline 16 & Description of any contact with authors & $4 ; 5$ \\
\hline \multicolumn{3}{|c|}{ Reporting of methods should include } \\
\hline 17 & Description of relevance or appropriateness of studies assembled for assessing the hypothesis to be tested & 6 \\
\hline 18 & Rationale for the selection and coding of data (e.g., sound clinical principles or convenience) & $3 ; 4$ \\
\hline 19 & Documentation of how data were classified and coded (e.g., multiple raters, blinding and inter-rater reliability) & 4 \\
\hline 20 & Assessment of confounding (e.g., comparability of cases and controls in studies where appropriate) & - \\
\hline 21 & $\begin{array}{l}\text { Assessment of study quality, including blinding of quality assessors, stratification or regression on possible predictors of } \\
\text { study results }\end{array}$ & 6 \\
\hline 22 & Assessment of heterogeneity & $6,7,8$ \\
\hline 23 & $\begin{array}{l}\text { Description of statistical methods (e.g., complete description of fixed or random-effects models, justification of whether } \\
\text { the chosen models account for predictors of study results, dose-response models or cumulative meta-analysis) in sufficient } \\
\text { detail to be replicated }\end{array}$ & 7 \\
\hline 24 & Provision of appropriate tables and graphics & $16-27$ \\
\hline \multicolumn{3}{|c|}{ Reporting of results should include } \\
\hline 25 & Graphic summarising individual study estimates and overall estimate & $25-26$ \\
\hline 26 & Table giving descriptive information for each study included & 17 \\
\hline 27 & Results of sensitivity testing (e.g., subgroup analysis) & 8 \\
\hline 28 & Indication of statistical uncertainty of findings & 11 \\
\hline
\end{tabular}


Appendix S2. PRISMA checklist.

\begin{tabular}{|c|c|c|c|}
\hline Section/topic & \# & Checklist item & $\begin{array}{l}\text { Reported on } \\
\text { page \# }\end{array}$ \\
\hline \multicolumn{4}{|l|}{ TITLE } \\
\hline Title & 1 & Identify the report as a systematic review, meta-analysis or both. & 1 \\
\hline \multicolumn{4}{|l|}{ ABSTRACT } \\
\hline Structured summary & 2 & $\begin{array}{l}\text { Provide a structured summary including as applicable: background; objectives; data sources; study eligibil- } \\
\text { ity criteria, participants and interventions; study appraisal and synthesis methods; results; limitations; } \\
\text { conclusions and implications of key findings and systematic review registration number. }\end{array}$ & 2 \\
\hline \multicolumn{4}{|l|}{ INTRODUCTION } \\
\hline Rationale & 3 & Describe the rationale for the review in the context of what is already known. & 4 \\
\hline Objectives & 4 & $\begin{array}{l}\text { Provide an explicit statement of questions being addressed with reference to participants, interventions, } \\
\text { comparisons, outcomes and study design (PICOS). }\end{array}$ & 4 \\
\hline \multicolumn{4}{|l|}{ METHODS } \\
\hline $\begin{array}{l}\text { Protocol and regis- } \\
\text { tration }\end{array}$ & 5 & $\begin{array}{l}\text { Indicate if a review protocol exists, if and where it can be accessed (e.g., Web address), and if available, } \\
\text { provide registration information including registration number. }\end{array}$ & 4 \\
\hline Eligibility criteria & 6 & $\begin{array}{l}\text { Specify study characteristics (e.g., PICOS and length of follow-up) and report characteristics (e.g., years } \\
\text { considered, language and publication status) used as criteria for eligibility, giving rationale. }\end{array}$ & 4 \\
\hline Information sources & 7 & $\begin{array}{l}\text { Describe all information sources (e.g., databases with dates of coverage and contact with study authors to } \\
\text { identify additional studies) in the search and date last searched. }\end{array}$ & 5 \\
\hline Search & 8 & $\begin{array}{l}\text { Present full electronic search strategy for at least one database, including any limits used, such that it } \\
\text { could be repeated. }\end{array}$ & 5 \\
\hline Study selection & 9 & $\begin{array}{l}\text { State the process for selecting studies (i.e., screening, eligibility, included in systematic review, and, if ap- } \\
\text { plicable, included in the meta-analysis). }\end{array}$ & 5 \\
\hline $\begin{array}{l}\text { Data collection } \\
\text { process }\end{array}$ & 10 & $\begin{array}{l}\text { Describe the method of data extraction from reports (e.g., piloted forms, independently, in duplicate) and } \\
\text { any processes for obtaining and confirming data from investigators. }\end{array}$ & 5 \\
\hline Data items & 11 & $\begin{array}{l}\text { List and define all variables, for which data were sought (e.g., PICOS and funding sources) and any assump- } \\
\text { tions and simplifications made. }\end{array}$ & $1 ; 4$ \\
\hline $\begin{array}{l}\text { Risk of bias in indi- } \\
\text { vidual studies }\end{array}$ & 12 & $\begin{array}{l}\text { Describe methods used for assessing the risk of bias of individual studies (including specification of } \\
\text { whether this was done at the study or outcome level), and how this information is to be used in any data } \\
\text { synthesis. }\end{array}$ & 6 \\
\hline Summary measures & 13 & State the principal summary measures (e.g., risk ratio and difference in means). & 7 \\
\hline Synthesis of results & 14 & $\begin{array}{l}\text { Describe the methods of handling data and combining results of studies, if done, including measures of } \\
\text { consistency }\left(\text { e.g., }\left.\right|^{2}\right) \text { for each meta-analysis. }\end{array}$ & 7 \\
\hline
\end{tabular}


Page 1 of 2

\begin{tabular}{|c|c|c|c|}
\hline Section/topic & \# & Checklist item & $\begin{array}{l}\text { Reported on } \\
\text { page \# }\end{array}$ \\
\hline $\begin{array}{l}\text { Risk of bias across } \\
\text { studies }\end{array}$ & 15 & $\begin{array}{l}\text { Specify any assessment of the risk of bias that may affect the cumulative evidence (e.g., publication bias } \\
\text { and selective reporting within studies). }\end{array}$ & 8 \\
\hline Additional analyses & 16 & $\begin{array}{l}\text { Describe the methods of additional analyses (e.g., sensitivity or subgroup analyses and meta-regression), if } \\
\text { done, indicating which were pre-specified. }\end{array}$ & 7 \\
\hline \multicolumn{4}{|l|}{ RESULTS } \\
\hline Study selection & 17 & $\begin{array}{l}\text { Give the number of studies screened, assessed for eligibility and included in the review, with reasons for } \\
\text { exclusions at each stage, ideally with a flow diagram. }\end{array}$ & 7 \\
\hline $\begin{array}{l}\text { Study character- } \\
\text { istics }\end{array}$ & 18 & $\begin{array}{l}\text { For each study, the present characteristics for which data were extracted (e.g., study size, PICOS and } \\
\text { follow-up period) and provide the citations. }\end{array}$ & 7 \\
\hline $\begin{array}{l}\text { Risk of bias within } \\
\text { studies }\end{array}$ & 19 & Present data on the risk of bias of each study and, if available, any outcome level assessment (see item 12). & 8 \\
\hline $\begin{array}{l}\text { Results of individual } \\
\text { studies }\end{array}$ & 20 & $\begin{array}{l}\text { For all outcomes considered (benefits or harms), present, for each study: (a) simple summary data for each } \\
\text { intervention group (b) effect estimates and confidence intervals, ideally with a forest plot. }\end{array}$ & 8 \\
\hline Synthesis of results & 21 & Present results of each meta-analysis done, including confidence intervals and measures of consistency. & 8 \\
\hline $\begin{array}{l}\text { Risk of bias across } \\
\text { studies }\end{array}$ & 22 & Present results of any assessment of the risk of bias across studies (see Item 15). & 8 \\
\hline Additional analysis & 23 & $\begin{array}{l}\text { Give results of additional analyses, if done (e.g., sensitivity or subgroup analyses and meta-regression [see } \\
\text { Item 16]). }\end{array}$ & 8 \\
\hline \multicolumn{4}{|l|}{ DISCUSSION } \\
\hline $\begin{array}{l}\text { Summary of evi- } \\
\text { dence }\end{array}$ & 24 & $\begin{array}{l}\text { Summarise the main findings including the strength of evidence for each main outcome; consider their } \\
\text { relevance to key groups (e.g., healthcare providers, users and policymakers). }\end{array}$ & 9 \\
\hline Limitations & 25 & $\begin{array}{l}\text { Discuss limitations at the study and outcome level (e.g., risk of bias) and at the review level (e.g., incom- } \\
\text { plete retrieval of identified research and reporting bias). }\end{array}$ & 10 \\
\hline Conclusions & 26 & $\begin{array}{l}\text { Provide a general interpretation of the results in the context of other evidence and implications for future } \\
\text { research. }\end{array}$ & 11 \\
\hline \multicolumn{4}{|l|}{ FUNDING } \\
\hline Funding & 27 & $\begin{array}{l}\text { Describe sources of funding for the systematic review and other support (e.g., supply of data); the role of } \\
\text { funders for the systematic review. }\end{array}$ & 1 \\
\hline
\end{tabular}

From: Moher D, Liberati A, Tetzlaff J, Altman DG, The PRISMA Group (2009). Preferred Reporting Items for Systematic Reviews and Meta-Analyses: The PRISMA Statement. PLoS Med 6(6): e1000097. doi:10.1371/journal.pmed1000097 
Appendix S3. Search strategy for each database.

\begin{tabular}{|c|c|}
\hline Database & Search Strategy \\
\hline PubMed & $\begin{array}{l}\text { (('breast neoplasms' [Mesh] OR 'breast cancer' OR 'metastatic breast cancer') AND 'stage IV') OR 'stage IV breast cancer' OR ('stage } \\
\text { IV metastatic breast cancer') AND ('lymph node excision' [Mesh] OR 'surgical excision' OR surgery OR 'local treatment') }\end{array}$ \\
\hline Embase & $\begin{array}{l}\text { ('breast'/exp OR breast AND ('tumour'/exp OR tumour) AND ('breast cancer' OR 'metastatic breast cancer') AND 'stage IV' OR } \\
\text { 'stage IV breast cancer' OR 'stage IV metastatic breast cancer') AND ('lymph node dissection'/exp OR 'surgical excision' OR surgery } \\
\text { OR 'local treatment') }\end{array}$ \\
\hline LILACS & $\begin{array}{l}\text { (tw: (breast neoplasms OR breast cancer OR metastatic breast cancer OR stage IV metastatic breast cancer)) AND (stw: (lymph } \\
\text { node excision OR surgical excision OR surgery OR local treatment)) }\end{array}$ \\
\hline SCIELO & (breast cancer OR metastatic breast cancer) AND (surgery OR surgical excision) \\
\hline Web of Science & $\begin{array}{l}\text { ((('breast neoplasms' OR 'breast cancer' OR 'metastatic breast cancer') AND 'stage IV') OR 'stage IV breast cancer' OR ('stage IV } \\
\text { metastatic breast cancer') AND ('lymph node excision' OR 'surgical excision' OR surgery OR 'local treatment')) }\end{array}$ \\
\hline Scopus & $\begin{array}{l}\text { TITLE-ABS-KEY ((('breast neoplasms' OR 'breast cancer' OR 'metastatic breast cancer') AND 'stage IV') OR 'stage IV breast cancer' } \\
\text { OR ('stage IV metastatic breast cancer') AND ('lymph node excision' OR 'surgical excision' OR surgery OR 'local treatment'))) }\end{array}$ \\
\hline Google Scholar & $\begin{array}{l}\text { ('breast neoplasms' OR 'breast cancer' OR 'metastatic breast cancer' OR 'stage IV breast cancer' OR 'stage IV metastatic breast } \\
\text { cancer') AND ('lymph node excision' OR 'surgical excision' OR surgery OR 'local treatment') }\end{array}$ \\
\hline Proquest & $\begin{array}{l}\text { (('breast neoplasms' OR 'breast cancer' OR 'metastatic breast cancer') AND 'stage IV') OR 'stage IV breast cancer' OR ('stage IV } \\
\text { metastatic breast cancer') AND ('Iymph node excision' OR 'surgical excision' OR surgery OR 'local treatment') }\end{array}$ \\
\hline Clinical Trials & $\begin{array}{l}\text { ('breast neoplasms' OR 'breast cancer' OR 'metastatic breast cancer' OR 'stage IV breast cancer' OR 'stage IV metastatic breast } \\
\text { cancer') AND ('lymph node excision' OR 'surgical excision' OR surgery OR 'local treatment') }\end{array}$ \\
\hline
\end{tabular}

